\title{
ORGANIC CHEMISTRY
}

\author{
M.Zh. Burkeev, A.Zh. Sarsenbekova, A.N. Bolatbay ${ }^{*}$, E.M. Tazhbaev, S.Zh. Davrenbekov, \\ E. Nasikhatuly, E.Zh. Zhakupbekova, A.A. Muratbekova \\ Karagandy University of the name of academician E.A. Buketov, Kazakhstan \\ (Corresponding author's e-mail: abylai_bolatbai@mail.ru)
}

\section{The use of differential calculation methods for the destruction of copolymers of polyethylene glycol fumarate with the acrylic acid}

\begin{abstract}
In this work, the thermal decomposition of copolymers based on polyethylene glycol fumarate with the acrylic acid using various ratios of initial monomers has been studied for the first time. The samples were studied in air and nitrogen. According to the thermograms analysis, it was found that the copolymer sample decomposition begins at higher temperatures for a copolymer with high content of polyester resin. The copolymer is vigorously oxidized by the oxygen when heated in air, and one can observe almost complete sample decomposition, whereas it decomposes with a residue of $\sim 15 \%$ in an inert medium. The activation energies for copolymers with different compositions were estimated using the differential methods of Freeman-Carroll, Achar and Sharpe-Wentworth. The activation energy values found by the three methods demonstrated a good convergence. It was shown that, the activation energy values are higher $(\sim 200 \mathrm{~kJ} / \mathrm{mol}$ in the inert medium, and $\sim 95 \mathrm{~kJ} / \mathrm{mol}$ in the oxygen atmosphere) for a copolymer with a lower composition of polyester resin, and the activation energy is $\sim 180$ and $\sim 85 \mathrm{~kJ} / \mathrm{mol}$ for a copolymer with a greater composition of $\mathrm{p}$-EGF-AA. The copolymer is more thermostable in the nitrogen atmosphere according to the kinetic parameters. Additionally, there were determined the thermodynamic characteristics, such as the Gibbs energy $(\Delta G)$ and the entropy $(\Delta S)$. They also confirm the destruction process dependence on the components ratio in the synthesized copolymer.
\end{abstract}

Keywords: dynamic thermogravimetry, decomposition, thermal destruction, copolymer, thermodynamic characteristics.

\section{Introduction}

Currently the volumes of produced unsaturated polyesters and materials based on them are annually increasing in the most industrialized countries. This is due to both the presence of a wide raw material base and the simplicity of processing polyesters into products, and the possibility of obtaining on their basis a large number of different materials with various practically valuable properties [1].

One of the most promising comonomers for getting new «smart» materials based on the unsaturated polyesters are unsaturated carboxylic acids, where the presence of carboxyl groups in the main chain determines their physicochemical behavior [2]. In this case, the interaction of unsaturated polyesters with above monomers of vinyl series was referred to the copolymerization reactions by V.G. Benig [3], whose monograph contains extensive data on the interaction of the above polyesters with styrene, vinyl acetate, methyl methacrylate and a number of other compounds. And there has been no information on the unsaturated polyesters copolymerization with the ionic monomers prior to the work carried out by the authors [4], that opens up prospects for the «smart» materials synthesis and significantly expand the scope of their application.

\footnotetext{
${ }^{*}$ Corresponding author
} 
Previously, the authors of [5] by the radical copolymerization of unsaturated polyester resins with a number of unsaturated carboxylic acids have synthesized copolymers with carboxyl groups in the side chains and showing sensitivity to various environmental changes.

Continuing the work, it seemed interesting to evaluate the thermal stability of the previously synthesized copolymers of polyethylene glycol fumarate with the acrylic acid under the dynamic conditions in the inert atmosphere and in the air.

\section{Experimental}

Previously synthesized copolymers of polyethylene glycol fumarate (p-EGF) with the acrylic acid (AA) (7.95:92.05 and 89.05:10.95 molar ratio) have been used as the objects of study [6-7]. The study of the copolymers thermal properties was performed using a synchronous TGA/DSC thermal analyzer LabSYS evo DTA/DSC (Setaram, France) in the dynamic mode within the $30-1000{ }^{\circ} \mathrm{C}$ temperature range. The heated rate was $10^{\circ} \mathrm{C} \cdot \mathrm{min}^{-1}$ in nitrogen and air atmosphere, and the flow rate was $30 \mathrm{ml} \cdot \mathrm{min}^{-1}$ in a crucible of $\mathrm{Al}_{2} \mathrm{O}_{3}$. The sample weight was 10-12 mg. Experimental data processing was performed using Microsoft Excel and Processing programs.

\section{Results and Discussion}

As previously shown, the unsaturated polyester resins' copolymers with unsaturated carboxylic acids have a number of practically valuable properties, thus it was interesting to evaluate their thermal stability.

The copolymers thermal stability in various temperature ranges allows us to predict the possibility of their use in certain areas. The study objects used are the 7.95:92.05 and 89.05:10.95 molar ratio copolymers of polyethylene glycol fumarate with acrylic acid with the «smart-systems» and sealants properties, respectively.

The composition and properties of polyethylene glycol fumarate with the acrylic acid copolymers obtained by the radical copolymerization in solution are shown in the Table 1.

$\mathrm{Tab}$ e 1

Composition and properties of the copolymers of p-EGF (M1) with AA (M2)

\begin{tabular}{|c|c|c|c|c|c|}
\hline \multicolumn{2}{|c|}{ Composition of initial mixture, mol. \% } & \multicolumn{2}{|c|}{ Composition of copolymer, mol. \% } & \multirow{2}{*}{$\alpha, \%$ Yield, \% } \\
\cline { 1 - 4 } $\mathrm{M}_{1}$ & $\mathrm{M}_{2}$ & $\mathrm{~m}_{1}$ & \multicolumn{2}{c|}{$\mathrm{m}_{2}$} & \\
\hline \multicolumn{7}{|c|}{ p-EGF:AA } \\
\hline 10.09 & 89.91 & 7.95 & 92.05 & 1412 & 88.23 \\
\hline 90.08 & 9.92 & 89.05 & 10.95 & 512 & 63.02 \\
\hline
\end{tabular}

The Table 1 data comparison represents that the swelling ratio $(\alpha)$ decreases, and the content of maleate groups increases under reducing of the acrylic acid fraction in the copolymer content; it appears to be related to a decrease in side chains and an increase in the polyethylene glycol fumarate fraction.

In this work, we have evaluated the thermal degradation of p-EGF:AA copolymers using the dynamic thermogravimetric analysis. The Figures 1, 2 show thermograms for the 7.95:92.05 and 89.05:10.95 molar ratio copolymers of polyethylene glycol fumarate with the acrylic acid with the $10{ }^{\circ} \mathrm{C} \cdot \mathrm{min}^{-1}$ constant heating rate at the temperature range of $30-1000{ }^{\circ} \mathrm{C}$ in the nitrogen and air atmosphere.

As can be seen in Figure1 on the thermogravimetric curves, both substances do not undergo any transformations leading to a mass change in the $30^{\circ} \mathrm{C}$ to $150{ }^{\circ} \mathrm{C}$ temperature range. There is observed a slight decomposition with the release of volatile products and a weight loss of up to $\sim 12 \%$ for a 7.95:92.05 mol.\% copolymer in the $200-330^{\circ} \mathrm{C}$ temperature range. Then, an intensive decrease in the sample mass occurs with the process total completion at a $\sim 600^{\circ} \mathrm{C}$ temperature. Total weight loss is $\sim 80 \%$. The release process of volatile substances begins at higher temperatures and reaches its maximum at $320^{\circ} \mathrm{C}$ for the copolymer with a high content of polyester resin. There is composition of the copolymer's basic mass with the total residue of $\sim 15 \%$ in the $340-500{ }^{\circ} \mathrm{C}$ temperature range.

There is observed a slight change in the rate in the range from 0 to $0.11 \mathrm{mg} \cdot \mathrm{min}^{-1}$ for both copolymers on the curves of the mass loss rate (Fig. 1, b) in the $30-260^{\circ} \mathrm{C}$ temperature range. A sharp increase in the rate is observed for the copolymer with a high content of acrylic acid at the above $300{ }^{\circ} \mathrm{C}$ temperature range. There is observed a shift to high temperatures, achieving its $1.7 \mathrm{mg} \cdot \mathrm{min}^{-1}$ numerical value maximum at 
$400{ }^{\circ} \mathrm{C}$. A peak is observed for a $89.05: 10.95 \mathrm{~mol} . \%$ copolymer at $350{ }^{\circ} \mathrm{C}$, and then a gradual decrease in rate occurs with stabilization in the region of $\sim 500^{\circ} \mathrm{C}$ for both copolymers.

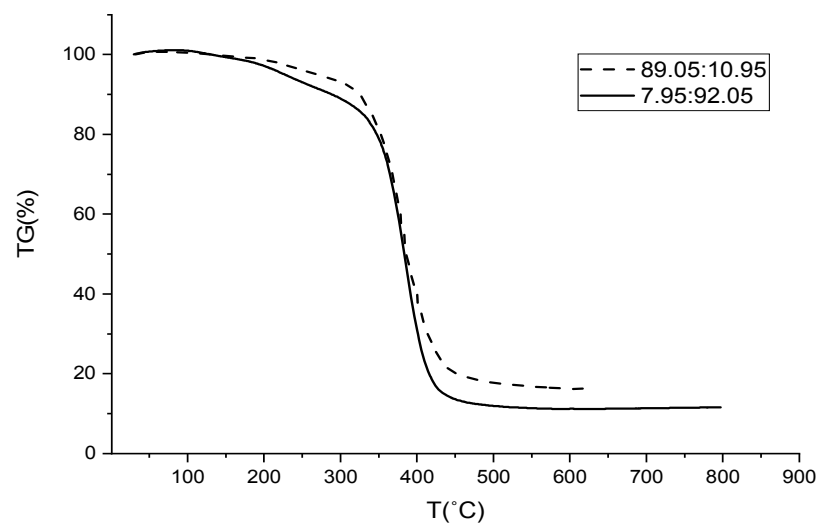

a)

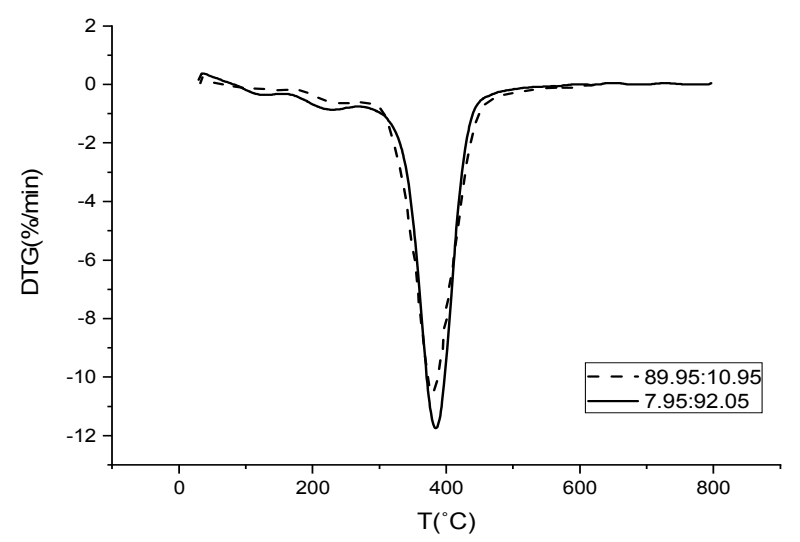

b)

Figure 1. Temperature dependences of mass change (TG curve) (a), mass change rate (DTG curve) $(b)$ for p-EGF:AA copolymers with 7.95:92.05 mol.\% and 89.05:10.95 mol.\% initial ratios M1:M2

(in nitrogen atmosphere)

Continuing the work, the thermogravimetric studies of the p-EGF copolymers with AA in air were carried out. From the data obtained by comparison (Fig. 2, a), it can be seen that the 7.95:92.05 mol.\% copolymer of polyethylene glycol fumarate with acrylic acid begins to decompose at a temperature of $200{ }^{\circ} \mathrm{C}$ when heated in air. An intensive decrease in the sample mass occurs followed by a gradual decomposition in the $300-420^{\circ} \mathrm{C}$ temperature range. The afterburning phase accompanied by almost a complete decomposition of the copolymer can observed on the thermogravimetric curves. A copolymer with a high content of polyester resin begins to decompose at the lower temperatures, a shift to high temperatures is also observed. The substance does not undergo transformation leading to a change in its mass in the temperature range from $30{ }^{\circ} \mathrm{C}$ to $100{ }^{\circ} \mathrm{C}$. Further, there is a slight decomposition with the release of volatile products. An intensive decrease in the sample mass occurs in the $300-430^{\circ} \mathrm{C}$ temperature range, after which there is a gradual decomposition of the copolymer with the total process completion at the $750^{\circ} \mathrm{C}$.

There is observed a slight change in the rate from 0 to $0.24 \mathrm{mg} \cdot \mathrm{min}^{-1}$ in the $30-300{ }^{\circ} \mathrm{C}$ temperature range on the curves of the mass loss rate (Fig. 2, b). The curve shows a peak at $392^{\circ} \mathrm{C}$ for the copolymer with a lower acrylic acid content, and for the p-EGF:AA copolymer 7.95:92.05 the peak is observed at $375^{\circ} \mathrm{C}$ with a numerical value of $\sim 1.9 \mathrm{mg} \cdot \mathrm{min}^{-1}$. 


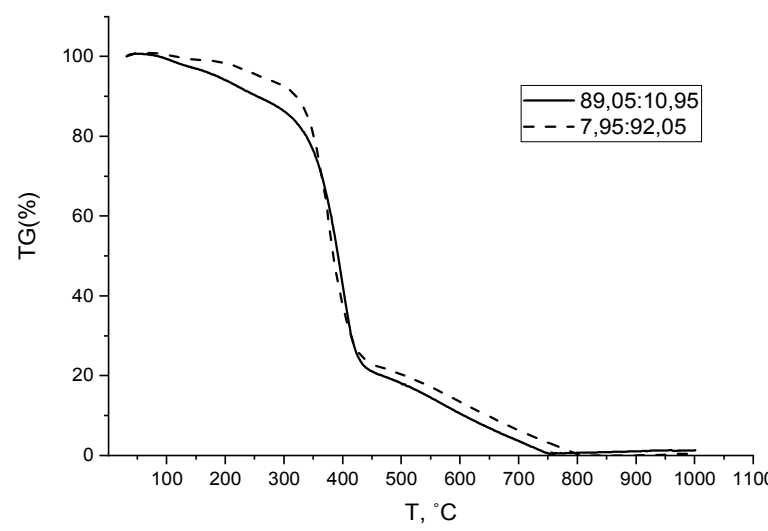

a)

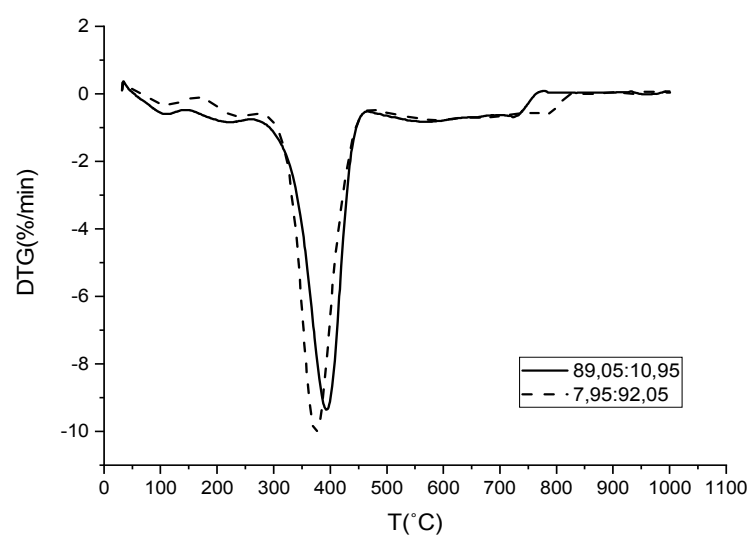

b)

Figure 2. Temperature dependences of mass change (TG curve) ( $a$ ), mass change rate (DTG curve) $(b)$ for p-EGF:AA copolymers with 7.95:92.05 mol.\% and 89.05:10.95 mol.\% initial ratios M1:M2 (in air)

Based on the copolymers thermal analysis result obtained, the activation energy and the reaction order were calculated using the methods of Achar [8], Sharp-Wentworth [9] and Freeman-Carroll [10] (Fig. 3). By comparing the graphs obtained using different methods, it can be conclude that the points have a larger scatter for the Freeman-Carroll method (Fig. 3, c), that leads to an error in estimating the activation energy. So, the line intersects the ordinate axis at the point +33.17 and has a slope corresponding to activation energy equal to $196.13 \mathrm{~kJ} / \mathrm{mol}$. Principally, the Achar and Sharp-Wentworth methods give the same results. The correlation coefficient of these three methods has a good convergence and tends to unity.

Such thermodynamic characteristics as change in Gibbs energy $(\Delta G)$ and entropy $(\Delta S)$ have been calculated using the obtained values of the activation energy (Table 2).

T a b le 2

Kinetic parameters of thermal degradation of the p-EGF:AA copolymer in air and nitrogen atmosphere

\begin{tabular}{|c|c|c|c|c|c|c|}
\hline \multirow{3}{*}{$\begin{array}{c}\mathrm{M}_{1}: \mathrm{M}_{2} \\
\text { copolymer } \\
\text { composition, mol.\% }\end{array}$} & \multicolumn{6}{|c|}{ Methods } \\
\hline & \multirow{2}{*}{$\begin{array}{c}\text { Achar } \\
\mathrm{E}, \mathrm{kJ} / \mathrm{mol}\end{array}$} & \multirow{2}{*}{$\frac{\mathrm{S}-\mathrm{W}}{\mathrm{E}, \mathrm{kJ} / \mathrm{mol}}$} & \multicolumn{4}{|c|}{ F-C } \\
\hline & & & $\mathrm{E}, \mathrm{kJ} / \mathrm{mol}$ & $\mathrm{n}$ & $\Delta \mathrm{S}, \mathrm{J} /(\mathrm{mol} \cdot \mathrm{K})$ & $\Delta \mathrm{G}, \mathrm{kJ} / \mathrm{mol}$ \\
\hline \multicolumn{7}{|c|}{ Nitrogen } \\
\hline 7.95:92.05 & 196.13 & 196.18 & 211.09 & 0.37 & -177.68 & 85.47 \\
\hline $89.05: 10.95$ & 165.11 & 165.45 & 190.12 & 0.61 & -94.65 & 101.65 \\
\hline \multicolumn{7}{|c|}{ Air } \\
\hline 7.95:92.05 & 95.06 & 95.08 & 94.09 & 0.36 & -192.32 & 143.37 \\
\hline $89.05: 10.95$ & 81.06 & 81.08 & 93.09 & 0.71 & -84.60 & 108.63 \\
\hline
\end{tabular}




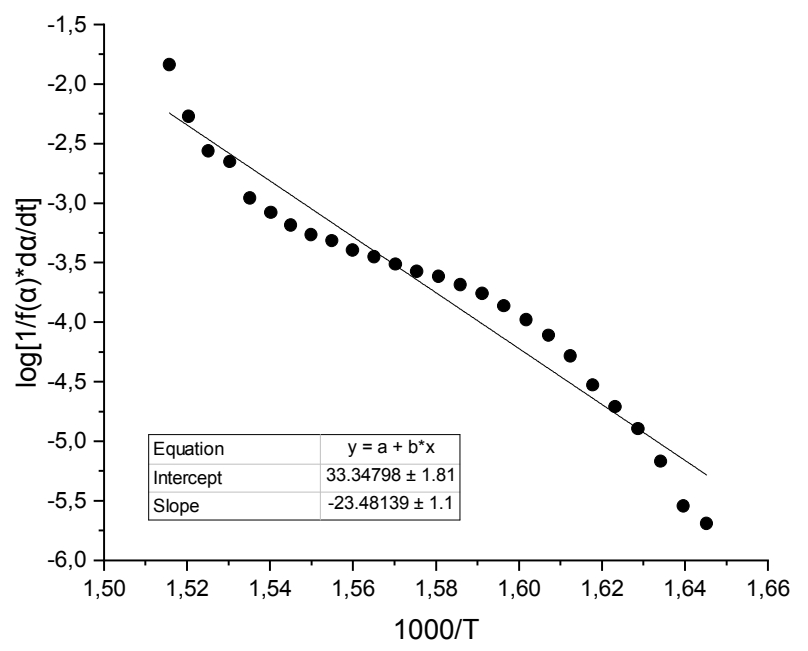

a)

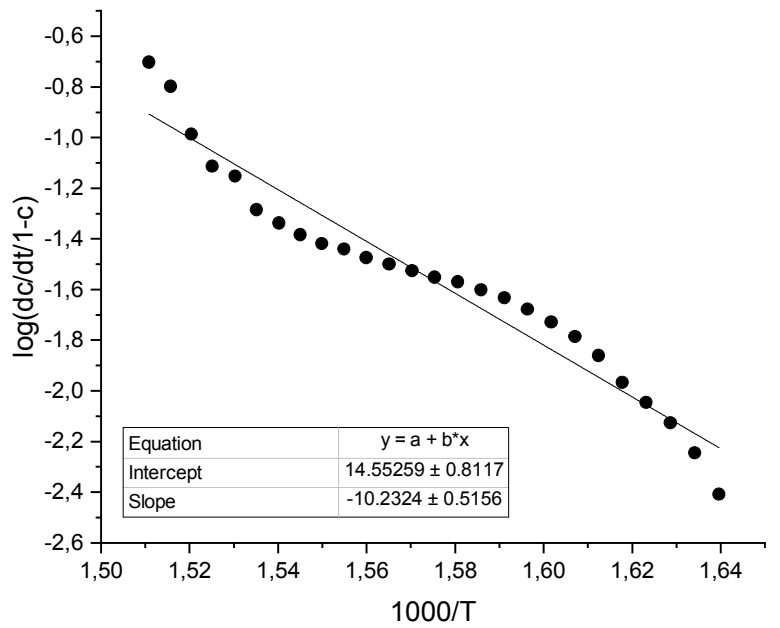

b)

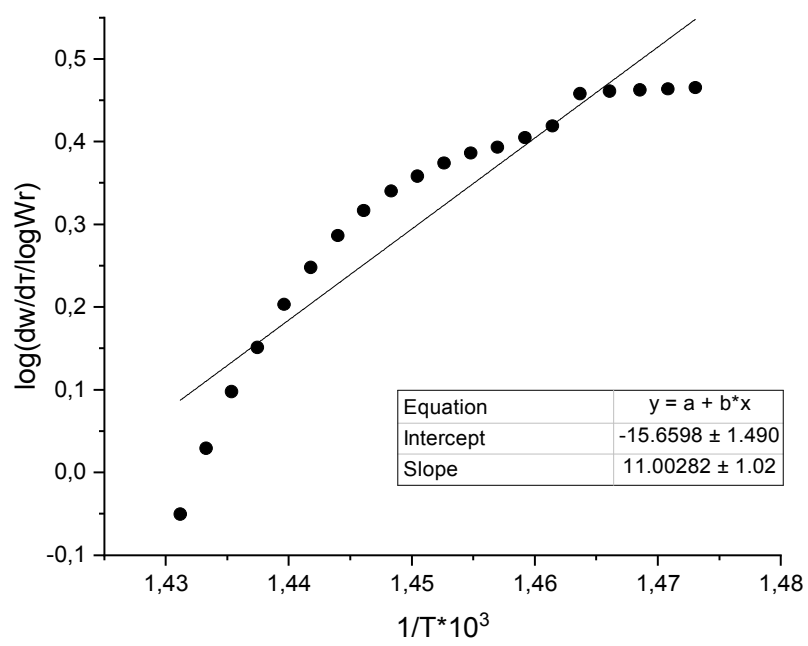

c)

Figure 3. Linearization of thermogravimetric data of the studied 7.95:92.05 mol.\% p-EGF: AA copolymer, using (a) Achar, (b) Sharp-Wentworth, (c) Freeman-Carroll method $\left(10^{\circ} \mathrm{C} \cdot \mathrm{min}^{-1}\right.$ heating rate, nitrogen atmosphere) 
The Table 2 shows the values of the activation energies of destruction obtained from the TGA data. As follows from the table, the dependence of the activation energy from the copolymers composition is extreme. The copolymers of the composition 7.95: 92.05 mol.\% have a higher value of activation energy. The activation energy value decreases with an increase in the composition of polyethylene glycol fumarate. It is in the range of 81-90 kJ/mol for the copolymer with the composition of $7.95: 92.05 \mathrm{~mol} . \%$ in the nitrogen atmosphere. It can be note, that calculated using the Freeman-Carroll method parameters have higher values, while the Achar and Sharpe-Wentworth methods give the same results. The positive value of the Gibbs energy $\Delta G$ and its growth with an increase in the copolymer composition of the unsaturated polyester p-EGF indicates the impossibility of spontaneous implementation of the destruction process.

Thermal destruction in the air atmosphere leads to a decrease in the thermal stability of copolymers. Due to that its effective activation energy is relatively small. This indicates that the polymer temperature resistance in air is lower than in inert medium.

\section{Conclusions}

Thus, the kinetic characteristics and thermodynamic parameters of copolymers of polyethylene glycol fumarate with the acrylic acid were determined for the first time. The activation energy values, calculated by the methods of Freeman-Carroll, Sharp-Wentworth and Achar, confirm the destruction process dependence on the components ratio in the synthesized copolymer. It was found that, the activation energy values have higher values with an increase in the content of the unsaturated polyester copolymer p-EGF. The copolymer is less thermostable when heated in the air. If the material is heated in absence of air, i.e. in the nitrogen atmosphere, the copolymer is split into low molecular weight products.

\section{References}

1 Benny C. Epoxidized Phenolic Novolac: A Novel Modifier for Unsaturated Polyester Resin. / C. Benny, T.T. Eby // Journal of Applied Polymer Science. — 2006. - Vol. 1. - P. 457.

2 Kandelbauer A. In Handbook of Thermoset Plastics / A. Kandelbauer, G. Tondi, O.C. Zaske, S.H. Goodman. - Amsterdam: Elsevier Inc. Chapters, 2014. - P. 6-111.

3 Boenig H.V. Unsaturated Polyesters. Structure and Properties / H.V. Boenig. - Amsterdam: Elsevier Publishing Company,

$4 \mathrm{Wu}$ Y. Acrylatedepoxidized soybean oil as a styrene replacement in a dicyclopentadiene-modified unsaturated polyester resin / Y. Wu, K. Li // Journal of Applied Polymer Science. — 2018. — Vol. 135, № 19. — P. 46212.

5 Burkeev M.Zh. Thermal destruction of copolymers of polypropylene glycol maleate with acrylic acid / M.Zh. Burkeev, A.Zh. Sarsenbekova, E.M. Tazhbaev // Russian Journal of Physical Chemistry A. — 2015. — Vol. 89, № 12. — P. $2183-2189$.

6 Burkeev M.Zh. New polyampholyte polymers based on polypropylene glycol fumarate with acrylic acid and dimethylaminoethyl methacrylate / M.Zh. Burkeev, G.K. Kudaibergen, G.K. Burkeeva et al. // Russian Journal of Applied Chemistry. — 2018. - Vol. 91, № 7. - P. 1145-1152.

7 Burkeev M.Zh. Comparative analysis of the thermal decomposition kinetics of polyethylene glycol fumarate-acrylic acid copolymers / M.Zh. Burkeev, G.K. Kudaibergen et al. // Russian Journal of Physical Chemistry A. — 2019. — Vol. 93, № 7. P. 1252-1257.

8 Achar B.N. Kinetics and mechanism of dehydroxylation processes, III, applications and limitations of dynamic methods / B.N. Achar, G.W. Brindley, J.H. Sharp // Proc. Int. Clay. Conf. - 1966. - P. 67-73.

9 Sharp J.H. Kinetic analysis of thermogravimetric data / J.H. Sharp, S.A. Wentworth // Anal. Chem. — 1969. — Vol. 41, № 14. - P. 2060.

10 Freeman E.S. The application of thermoanalytical techniques to reaction kinetics: The thermogravimetric evaluation of the kinetics of the decomposition of calcium oxalate monohydrate / E.S. Freeman, B. Carroll // J. Phys. Chem. 1958. — Vol. 62, № 4. — P. 394-397.

М.Ж. Буркеев, А.Ж. Сарсенбекова, А.Н. Болатбай, Е.М. Тажбаев, С.Ж. Давренбеков, Е. Насихатұлы, Э.Ж. Жакупбекова, А.А. Муратбекова

\section{Полиэтиленгликольфумарат пен акрил қышқылы негізіндегі сополимерлердің термиялық ыдырауына дифференциалды есептеу әдістерін қолдану}

Жұмыста бастапқы мономерлердің әртүрлі қатынастарында полиэтиленгликольфумарат пен акрил қышқылы негізіндегі сополимерлердің термиялық ыдырауы алғаш рет зерттелді. Үлгілерді зерттеу ауа мен азот ортасында жүргізілді. Термогравиметриялық қисықтарды талдау нәтижелері бойынша полиэфирлі шайыры көп құрамды сополимер үлгісінің ыдырауы жоғары температураларда 
басталатыны анықталды. Ауа атмосферасында қыздыру кезінде сополимер оттегінің әсерінен қатты тотығады және қисықтардан үлгінің толық ыдырауын байқауға болады, ал инертті ортада сополимер шамамен $\sim 15 \%$ қалдығымен ыдырайды. Фримен-Кэррол, Ахар және Шарп-Уэнтворттың дифференциалдық әдістері негізінде әртүрлі құрамды сополимерлердің активтендіру энергиясы анықталды. Үш әдіс арқылы анықталған активтендіру энергиясының мәндері жақсы бір-бірімен үйлесімдік көрсетеді. Полиэфирлі шайырдың аз құрамы бар сополимер үшін активтендіру энергиясының мәні жоғары ( 200 кДж/моль инертті ортада және оттегі атмосферасында 95 кДж/моль), ал п-ЭГФ-АҚ үлкен құрамы бар сополимер үшін активтендіру энергиясы 180 және $\sim 85$ кДж/моль құрайды. Кинетикалық параметрлер бойынша азот атмосферасында сополимер термостенді. Сонымен қатар, Гиббс энергиясы $(\Delta G)$ және энтропия $(\Delta S)$ сияқты кейбір термодинамикалық сипаттамалар анықталды, олар да деструкция үрдісінің синтезделген сополимердегі компоненттердің құрамына тәуелділігін растайды.

Кілm сөздер: динамикалық термогравиметрия, ыдырау, термиялық деструкция, сополимер, термодинамикалық сипаттамалар.

\title{
М.Ж. Буркеев, А.Ж. Сарсенбекова, А.Н. Болатбай, Е.М. Тажбаев, С.Ж. Давренбеков, Е. Насихатулы, Э.Ж. Жакупбекова, А.А. Муратбекова
}

\section{Использование дифференциальных методов расчета при деструкции сополимеров полиэтиленгликольфумарата с акриловой кислотой}

\begin{abstract}
В статье впервые изучено термическое разложение сополимеров на основе полиэтиленгликольфумарата с акриловой кислотой с различными соотношениями начальных мономеров. Исследование образцов проводилось в среде воздуха и азота. По результатам анализа термогравиметрических кривых установлено, что для сополимера с большим содержанием полиэфирной смолы разложение образца сополимера начинается при более высоких температурах. При нагревании в атмосфере воздуха сополимер энергично окисляется под воздействием кислорода и на кривых можно наблюдать почти полное разложение образца, тогда как в инертной среде сополимер разлагается с остатком $15 \%$. Дифференциальными методами Фримена-Кэррола, Ахара и Шарпа-Уэнтворта оценены энергии активации для сополимеров с различным составом. Найденные тремя методами значения энергии активации показывают хорошую сходимость. Установлено, что для сополимера с меньшим содержанием полиэфирной смолы значения энергии активации имеют более высокие показатели ( 200 кДж/моль в инертной среде и $\sim 95$ кДж/моль в атмосфере кислорода), а для сополимера с большим содержанием пЭГФ-АК энергия активации составляет $\sim 180$ и $~ 85$ кДж/моль. По кинетическим параметрам видно, что в атмосфере азота сополимер более термостабилен. Кроме того, были определены некоторые термодинамические характеристики, такие как энергия Гиббса $(\Delta \mathrm{G})$ и энтропия $(\Delta \mathrm{S})$, которые также подтверждают зависимость процесса деструкции от соотношения компонентов в синтезированном сополимере.
\end{abstract}

Ключевые слова: динамическая термогравиметрия, разложение, термическая деструкция, сополимер, термодинамические характеристики.

\section{References}

1 Benny, C., \& Eby, T.T. (2006). Epoxidized Phenolic Novolac: A Novel Modifier for Unsaturated Polyester Resin. Journal of Applied Polymer Science, 1, 457.

2 Boenig, H.V. (1964). Unsaturated Polyesters. Structure and Properties. Amsterdam: Elsevier Publishing Company.

3 Kandelbauer, A. (2014). In Handbook of Thermoset Plastics. Amsterdam: Elsevier Inc. Chapters. 6, 111.

$4 \mathrm{Wu}, \mathrm{Y} .$, \& Li, K. (2018). Acrylated epoxidized soybean oil as a styrene replacement in a dicyclopentadiene-modified unsaturated polyester resin. Journal of Applied Polymer Science, 135(19), 46212.

5 Burkeev, M.Zh., Sarsenbekova, A.Zh., \& Tazhbaev, E.M. (2015). Thermal destruction of copolymers of polypropylene glycol maleate with acrylic acid. Russian Journal of Physical Chemistry A, 89(12), 2183-2189.

6 Burkeev, M.Zh., Kudaibergen, G.K., \& Burkeeva, G.K., et al. (2018). New polyampholyte polymers based on polypropylene glycol fumarate with acrylic acid and dimethylaminoethyl methacrylate. Russian Journal of Applied Chemistry, 91(7), $1145-1152$.

7 Burkeev, M.Zh., Sarsenbekova, A.Zh., \& Kudaibergen, G.K., et al. (2019). Comparative analysis of the thermal decomposition kinetics of polyethylene glycol fumarate-acrylic acid copolymers. Russian Journal of Physical Chemistry A, 93(7), $1252-1257$.

8 Achar, B.N., Brindley, G.W., \& Sharp, J.H. (1966). Kinetics and mechanism of dehydroxylation processes, III, applications and limitations of dynamic methods. Proc. Int. Clay. Conf., 67-73.

9 Sharp, J.H., \& Wentworth, S.A. (1969). Kinetic analysis of thermogravimetric data. Anal. Chem., 41(14), 2060.

10 Freeman, E.S., Carroll, B. (1958). The Application of Thermoanalytical Techniques to Reaction Kinetics: The Thermogravimetric Evaluation of the Kinetics of the Decomposition of Calcium Oxalate Monohydrate. Journal of Physical Chemistry, 62(4), 394-397. 